\title{
Quality of Accounting Information, Executives' Background and Loans of Small and Medium-Sized Enterprises
}

\author{
Hu Guohui", Zheng Meimei, Zhao Le \\ School of Economics, Wuhan University of Technology, Wuhan, China \\ Email address: \\ 1654236438@qq.com (Hu Guohui),1159866718@qq.com (Zheng Meimei),1126624887@qq.com (Zhao Le) \\ ${ }^{*}$ Corresponding author
}

\section{To cite this article:}

$\mathrm{Hu}$ Guohui, Zheng Meimei, Zhao Le. Quality of Accounting Information, Executives' Background and Loans of Small and Medium-Sized Enterprises. International Journal of Economics. Finance and Management Sciences. Vol. 6, No. 5, 2018, pp. $216-223$.

doi: $10.11648 /$ j.ijefm.20180605.13

Received: August 20, 2018; Accepted: October 22, 2018; Published: November 8, 2018

\begin{abstract}
Small and medium-sized enterprises (SMEs) in China are currently still facing serious lending constraints, especially long-term loan constraints. This paper empirically studies on how the accounting information quality and executives' background of SMEs influence their credit availability and loan term structures. We use panel data from 2010 to 2015 of Chines SMEs financial report database, matched with the executive characteristic database. The findings suggest that with better accounting information quality or the executives' financial or political background, SMEs' short-term credit availability can be improved. Furthermore, the impact of executives' financial background is the largest. As for the long-term credit availability, the quality of accounting information plays a more important role than the executives' background. In addition, the interaction between quality of accounting information and executives' background on SMEs' credit availability varies in different terms of loans, showing supplementary effect for short-term loans and substitute effect for long-term loans.
\end{abstract}

Keywords: SMEs, Quality of Accounting Information, Executives' Background, Credit Availability, Credit Term Structure

\section{Introduction}

Small and medium-sized enterprises are an important force to facilitate our country's economic development, but the survival and development situation of small and medium-sized enterprises in our country is getting worse and the acute financing constraint is one of the key resistance to the development of small and medium-sized enterprises. In the bank-dominated financial system, bank credit is an important source of enterprise financing in our country. However, small and medium-sized enterprises have a high frequency of capital demand and risk, and banks are not willing to lend to them, which lead that the credit constraint problem of SMEs is still very serious, especially for long-term financing. This paper focuses on the term structure of credit for two reasons: On the one hand, the existing literature pays more attention on the credit availability of small and medium-sized enterprises, but the study on the credit term structure of SMEs is relatively lacking; On the other hand, as banks face a higher default risk in long term credit operations [1], the long term credit discrimination suffered by SMEs is even more serious. The credit structure based on short-term bank credit makes the capital chain of SMEs unstable and hinders their stable operation and sustainable development [2]. Therefore, it is of great practical significance to study the credit term structure of SMEs.

When banks make credit decisions, they usually make specific terms of a credit contract based on the financial information of enterprises, such as loan amount, interest rate, term, etc. [3]. But the credibility of financial information is affected by the quality of accounting information: High-quality accounting information can fully and truthfully disclose the business results and financial status of enterprises, which is helpful for banks and other stakeholders to make reasonable and effective decisions; However, low-quality accounting information causes the problem of information asymmetry between banks and enterprises more serious. Once misstated information is identified by banks, banks will assume the credit default risk is higher, so the credit approval rate of enterprises, the size of credit gap, the credit structure and loan cost may possibly be affected [4].

However, the action of judging the enterprise management 
status and making credit decisions only according to the historical financial information may be lack of preciseness [5]. Especially for SMEs, compared with large enterprises, defects in financial management are more serious and thus credit decision-making only relying on financial information has certain limitations. Because the management power of SMEs is relatively centralized, executives often have decisive influence on the investment and financing decisions of enterprises [6, 7]. Therefore, non-financial information of enterprises can provide important soft information, especially the disclosure of executives characteristics. In the previous studies on executives characteristics, emphasis was placed on how executive education, age and the proportion of female executives affect bank credit [7, 8]. However, this paper will focus on the financial and political background characteristics of executives to study the impact on SMEs credit, especially on the term structure of credit. The reasons are as follows: In the stage of economic transition in China, the system construction is not perfect. The financial and political background of enterprise executives is helpful to form the recessive connection with financial institutions and government departments, so they can transmit the enterprise quality signal [9]. Commercial banks will tend to provide them with credit supporting that has larger scale, longer maturities and more favorable terms [10]. But some studies suggest that banks do not pay attention to the role of soft information in SMEs [11], so the executive background may not play the theoretical effect.

Based on the above analysis, this paper will study the mechanism and effect of credit availability and term structure of SMEs from the quality of accounting information, the characteristics of executive background and the interaction of these two. This paper focuses on the following issues: (1) Does the quality of SMEs' accounting information affects their ability to obtain bank credit? If so, will the effect be significantly different on short-term and long-term loans? (2) Can the financial and political background of executives promote bank loan of SMEs? Is there a difference in the effect of the two on different term credit? (3) Is there any interaction between the quality of accounting information and the characteristics of executive background on the loan effect of SMEs? Facing different accounting information quality, whether the impact of executive background characteristics on loan effect changes and whether it has different effects on the term structure of loans?

From the perspective of the quality of accounting information and the background characteristics of executives, this paper studies the cross-effects of financial information and typical non-financial information on the credit availability of SMEs and the impact on the term structure of credit. This research will enrich the research production on the credit availability of SMEs, information theory and term structure theory, which will have some practical significance for the SMEs credit strategy and the bank loan decision-making. The remaining sections of this paper are arranged as follows: The second part reviews some relevant literature about the impact of accounting information quality and background characteristics of executives on enterprises credit availability and maturity structure and puts forward the relevant research hypotheses of this paper; The third part carries on the regression test to both each kind of factors mentioned above and the interaction between the factors, and analyzes the empirical results; The fourth part summarizes the research and puts forward the corresponding policy recommendations.

\section{Literature Review and Research Hypothesis}

\subsection{Quality of Accounting Information and Enterprise Credit}

Accounting information reveals the past business results and financial status of enterprises, and it is helpful for stakeholders to evaluate the current business development of enterprises and make reasonable prediction. In addition to comprehensibility, the most important feature of accounting information is the validity of decision-making, so the quality of accounting information is of great significance to credit decision-making. Since high-quality accounting information makes financial information of enterprises more reliable, banks tend to believe that default risk of loan is lower and are more willing to lend [12]. But in reality, the financial system of SMEs is not perfect. Thus the accounting information is incomplete or exists false component, which severely constrain the ability to access credit support [4, 13]. Although improving the quality of enterprise accounting information helps to alleviate the problem of information asymmetry, it often needs to invest a lot of funds. When the benefit of investment is less than the cost of it, enterprises are unwilling to improve the quality of accounting information and may even aggravate the moral hazard and adverse selection of SMEs [14].

The discrepancy of accounting information quality can also affect the term structure of loan to some extent. Bharath et al. pointed out that Bank of America has the ability to identify the quality of accounting information and can provide short term loans to enterprises with poor accounting information quality, while the possibility of providing collateral is also high [15]. Graham et al. pointed out when enterprises restate their financial statements, banks will doubt the quality of accounting information and will reduce the credit default risk by raising interest rates, shortening loan maturities, and increasing more mortgages, etc [16]. Lu Zhengfei et al. pointed out, for enterprises with different quality of accounting information, banks provide credit contract with differentiated loan rates, maturities and types to control default risk. For loans with different maturities, the banks' concern on accounting information would be different. Because the uncertainty of short-term borrowing is small, banks are more concerned about short-term solvency. While because the uncertainty of long-term borrowing is great, banks have higher requirements for the authenticity and adequacy of accounting information of enterprises [17]. Jiang Dongsheng pointed out that there are great differences in the proportion of 
long-term loans obtained by enterprises in different industries. The quality of enterprises accounting information is affected by earnings management level, and it has positive correlation with the proportion of long-term loans and negative correlation with borrowing costs [18].

Through the above analysis, this paper considers, for SMEs with high accounting information quality, the problem of information asymmetry between banks and enterprises is alleviated, the risk of credit default is small, and the availability of credit, especially the availability of long-term loans will improve. So this paper puts forward the following assumptions:

H1a: SMEs with higher accounting information quality have higher availability of credit.

H1b: SMEs with higher quality accounting information have a higher proportion of long-term loans available.

\subsection{Senior Executive Background Characteristics and Enterprise Credit}

In recent years, the influence of executive characteristics on enterprise credit has been paid close attention to, some related studies involving the effect of executive finance and political background on bank credit. In terms of financial background, Adam and Ferreira put forward that executives with financial backgrounds, as a bridge of communication between banks and enterprises, can enhance invisible cooperative relationships between banks and enterprises, provide expertise and guidance for corporate financing, and thus can accelerate the process of enterprise credit and enhance the credit capacity of enterprises [19]. Tang Jianxin found that enterprises can provide relational capital and professional credit guidance to enterprises by employing people with banking background as senior managers, in order to gain more bank loans [9]. In terms of political background, Faccio et al. studied the impact of political connection on government aid from 450 politically connected companies from 35 countries. The results showed that enterprises with political connections not only face smaller financing constraints, but also are more likely to get financial support from government when they are in financial trouble [20]. According to the empirical study on the political background of the senior executives of the private listed companies, Luo Danglun and Zhen Liming found that the political connections of private enterprises make the enterprises have a better reputation, making banks think that the default risk is relatively small, and thus the credit availability of the enterprises is higher. Moreover, in the areas with lower levels of financial development, the utility of political connections to corporate credit is even more significant [21]. Hong Yitian and Chen Jinlong studied the influence of enterprise relational capital on financing constraint and found that the political background of executives has no obvious influence on financing constraint. However, the social capital formed by the background of executive banking has a significant impact on alleviating corporate financing constraints [22].

The financial and political background of executives also has a certain impact on the term structure of enterprise credit.
For riskier long-term loans, creditors tend to have higher demands on systems such as justice. Under the background of imperfect system, the reputation and recessive guarantee mechanism formed by the financial and political background of enterprise executives can play a more important role in long-term loans. Ciamarra showed that the member of enterprise board of directors with banking experience not only increases the proportion of bank credit in the debt structure of enterprises, but also helps enterprises obtain long-term loans and reduce the proportion of mortgage loans [23]. Yu Minggui and Pan Hongbo pointed out that there are more uncertain factors in the long-term operation of enterprises and it is difficult to supervise long-term loans after banks' lending, while enterprises with political connections can easily get the protection of government policies and have relatively low operating risks. Therefore, compared to enterprises with no political connections, enterprises with political connections are more likely to obtain bank loans with longer maturities and more favorable terms [24][10]. Yuan Chunsheng pointed out that long-term loans are mainly used for projects such as enterprises expansion and large-scale investments. If projects are expected to drive regional economic growth, they will be strongly supported by government. Because the government still has considerable control over the allocation of financial resources, politically connected enterprises are more likely to obtain long-term loans [25].

Based on the above analysis, this paper argues that executives with government or banking experience can bring more social resources to SMEs, help banks identify corporate credit and development potential, and make SMEs have higher credit availability. So enterprises are also more likely to get long-term loans. Based on this, this paper proposes assumptions:

H2a: if the executives of SMEs have financial background, bank loan obtained by the SMEs is higher.

$\mathrm{H} 2 \mathrm{~b}$ : if the executives of SMEs have financial background, the proportion of long-term loans obtained by the SMEs is higher.

H3a: if the executives of SMEs have political background, bank loan obtained by the SMEs is higher.

$\mathrm{H} 3 \mathrm{~b}$ : if the executives of the SMEs have political background, the proportion of long-term loans obtained by the SMEs is higher.

\subsection{Quality of Accounting Information, Executive Background and Enterprise Credit}

According to the above analysis, the quality of accounting information and executive background characteristics of SMEs can affect the availability of credit in theory, but what kind of interaction will these two factors have to the loan effect of SMEs? Is it a substitute effect or a complementary effect? Combined with the research object of this paper, the meaning of the two effects can be understood as: When the quality of accounting information is low, if the loan effect of executive background is relatively strong, there is a substitution effect between the two factors; However, if the 
loan effect of the executive background is consistent with accounting information, there is a complementary effect between the two factors. At present, the system construction and financial development of our country are still deficient, and the quality of accounting information is low, so the relational capital of enterprises, especially the non-financial information such as executives background, can provide supplementary information for bank credit decision-making and its loan effect is obvious. But with the deepening of the reform of financial system, the system tends to be standardized so that creditors have higher demands on the quality of enterprise accounting information. To some extent, this can restrain the influence of the relational capital such as the executive background on the availability of credit. With the improvement of accounting information quality of SMEs, financial information can provide more effective information for banks loan decision-making, and enterprises will rely less on social capital such as executive background to acquire bank credit. The above analysises show that it is a substitution effect between the quality of accounting information and the executives' background on how to influence enterprises loan. Therefore, this paper puts forward the following assumptions:

H4: the lower the quality of accounting information is, the more obvious the SMEs' executive financial background affects bank loan.

H5: the lower the quality of accounting information is, the more obvious the SMEs' executive political background affects bank loan.

\section{Research and Design}

\subsection{Data Sources and Screening}

In this paper, the relevant data from 2010 to 2015 of SMEs is selected to form equilibrium panel data for empirical analysis. The data mainly comes from the financial report database and executive characteristic database of the Cathay CSMAR database and manually sort out the industry classification of the listed company according to the official website of CSRC. To ensure the integrity and applicability of the study data, the preliminary sample data should be properly filtered: (1) Remove companies with *St or St in sample data; (2) Exclude the listed companies in the financial industry; (3) Reject the enterprises that do not accord with "small and medium-sized enterprise pattern standard stipulate" (1). After screening, 495 samples were obtained in this empirical analysis, the data was preprocessed in Excel 2003, and the regression analysis of the model was carried out in STATA11.2. Considering the possible effect of extreme value, this paper deals with $1 \%$ winsorize for continuous variables.

\subsection{Indicator Description}

\subsubsection{Explained Variable}

Referring to the way that the scholars Rao Pingui and Jiang Guohua deal with bank credit [26], the bank credit availability $\mathrm{Y}_{1}$ is defined as the ratio of bank loans to operating income for small and medium-sized enterprises. Bank borrowing is the sum of short-term and medium-term loans, non-current liabilities due within one year and long-term loans in the balance sheet. Because the operating income is more closely related to the current business activities and capital demand, this paper selects the operating income, not the total assets, to eliminate the scale effect of enterprises. To investigate the effect of various explanatory variables on the term structure of credit, this paper defines short-term loan availability $\mathrm{Y}_{2}$ as the sum of short-term loans and non-current liabilities due in one year divided by operating income and long-term loan availability $\mathrm{Y}_{3}$ as long-term borrowing divided by operating income. The ratio of long-term loans to total bank credit is explained as long-term loans $\mathrm{Y}_{4}$.

\subsubsection{Main Explanatory Variable}

(1) quality of accounting information

Throughout the existing literature, many scholars use the modified Jones model to measure the quality of accounting information [17][27]. This paper also adopts the same method. Its basic principle is using related information on the enterprise financial statements to measure the enterprise manipulative accrual profit. The larger the profit is, the greater the degree of earnings management by changing accounting policies or structuring transactions is, the more likely it is to mislead the stakeholders to judge and make decisions on the business results, financial situation, etc. In other words, the larger the accrual profit of manipulation is, the worse the reliability of accounting information and the quality of accounting information are. The building process of the Jones model is as follows:

First, the total accrued profits $\mathrm{TAC}_{\mathrm{i}, \mathrm{t}}$ is calculated:

$$
T A C_{\mathrm{i}, t}=N I_{i, t}-C F O_{i, t}
$$

Of which, $\mathrm{NI}_{\mathrm{i}, \mathrm{t}}, \mathrm{CFO}_{\mathrm{i}, \mathrm{t}}$ are respectively Net profit and net cash flow of operating activities for phase i company $t$.

Secondly, the equation (2) is regressed,

$$
\begin{aligned}
& T A C_{i, t} / T A_{i, t-1}=\alpha_{0}+\alpha_{1}\left(1 / T A_{i, t-1}\right)+ \\
& \alpha_{2}\left(\Delta R E V_{i, t} / T A_{i, t-1}\right)+\alpha_{3}\left(\mathrm{PPE}_{\mathrm{i}, \mathrm{t}} / T A_{i, t-1}\right)+\mathcal{E}_{i, t}
\end{aligned}
$$

Then, the resulting coefficients $\alpha_{0}, \alpha_{1}, \alpha_{2}, \alpha_{3}$ are brought into the following formula (3) to calculate the non-manipulative accrual of profits $\mathrm{NDA}_{\mathrm{i}, \mathrm{t}}$ :

$$
\begin{aligned}
& N D A_{i, t} / T A_{i, t}=\alpha_{0}+\alpha_{1}\left(1 / T A_{i, t-1}\right)+\alpha_{2} \\
& \left(\left(\Delta R E V_{i, t}-\Delta R E C_{i, t}\right) / T A_{i, t-1}\right)+\alpha_{3}\left(P P E_{i, t} / T A_{i, t-1}\right)
\end{aligned}
$$

In equation (2) and (3), $\triangle \mathrm{REV}_{\mathrm{i}, \mathrm{t}}, \triangle \mathrm{REC}_{\mathrm{i}, \mathrm{t}}$ and $\mathrm{PPE}_{\mathrm{i}, \mathrm{t}}$ are prime operating revenue changes over the previous period, change in receivables, original value of fixed assets in phase $t$ of company $\mathrm{i} ; \mathrm{TA}_{\mathrm{i}, \mathrm{t}-\mathrm{1}}$ is total assets of company $\mathrm{i}$ at the end of t-1.

Finally, calculation of manipulative accrued profits adjusted for total asset $\mathrm{DA}_{\mathrm{i}, \mathrm{t}} / \mathrm{TA}_{\mathrm{i}, \mathrm{t}}$ :

$$
D A_{i, t} / T A_{i, t}=T A C_{i, t} / T A_{i, t-1}-N D A_{i, t} / T A_{i, t-1}
$$


According to the above formula, the manipulative accrual profit $\mathrm{DA}_{\mathrm{i}, \mathrm{t}} / \mathrm{TA}_{\mathrm{i}, \mathrm{t}}$ adjusted by assets is calculated. The smaller the manipulative accrual profit is, the higher the quality of accounting information is. Therefore, this paper takes the reciprocal of its absolute value as the accounting information quality index AQ. The higher the AQ value is, the higher the quality of accounting information is.

(2) Executive background feature variable TMB

Financial background of executives FB: The financial background of enterprise executives is helpful to form Bank-Enterprise relationship. According to the executive characteristic database, if an executive has worked or is working in a regulatory organization, a policy bank or a commercial bank, then set the virtual variable $\mathrm{EFB}=1$; While an executive has no corresponding financial background, set the $\mathrm{EFB}=0$. In this paper, the financial backgrounds of all executives in a given year are taken as the final financial background FB.

Political background of executives PB: Current executives who have served or are serving as deputies to the National people's Congress, members of the Chinese people's political Consultative Conference, or the party and government organizations are considered to have political affiliation PC, then set the $\mathrm{PC}=1$. While there is no political connection, set the $\mathrm{PC}=0$. At the same time, at the national level, the provincial level, the office level, the county level, the township level (including the following), the different political connection intensity is given as PCS5,4,3,2,1. The PC*PCS reflects the political background of the senior executives with different intensity. There are many executives with political background in a certain enterprise. In this paper, the total number of $\mathrm{PC} * \mathrm{PCS}$ in a certain year is taken as the final political background $\mathrm{PB}$ of the enterprise in that year.

\subsubsection{Control Variable}

Referring to the selection and setting of control variables by Guo Tianyong and Yu Minggui et al [11][10], this paper introduces the following data from the end of the last fiscal year as control variables: (1) The logarithm of income reflects the business scale and results of the enterprise; (2) Current ratio (LiqR) reflects enterprise's solvency; (3) Fixed assets ratio (FixR) reflects the proportion of assets that the enterprise can use for mortgage guarantee; (4) Asset return rate (Roa) reflects enterprise's profitability. In addition, annual virtual variable (year) is introduced to control unknown factors that change within the year.

\subsection{Model Setting}

$$
\begin{aligned}
& Y_{\mathrm{i}, t}=\alpha_{0}+\alpha_{1} A Q_{i, t}+\alpha_{2} F B_{i, t}+\alpha_{3} P B_{i, t} \\
& +\alpha \text { ControlVariables }+\varepsilon_{i, t} \\
& Y_{i, t}=\beta_{0}+\beta_{1} A Q_{i, t}+\beta_{2} T M B_{i, t}+ \\
& \beta_{3} A Q_{i, t} \times T M B_{i, t}+\beta \text { ControlVariables }+\mathcal{E}_{i, t}
\end{aligned}
$$

In equation 5, this paper takes the position of bank credit availability $Y_{1}$, short-term loan availability $Y_{2}$, long-term loan availability $Y_{3}$, and long-term loan ratio $Y_{4}$ to the explained variable $Y_{i, t}$ in turn, and carries out mixed regression to test the hypothesis 1a, 1b, 2a, 2b, 3a, and 3b. If the coefficients $\alpha_{1}, \alpha_{2}$ and $\alpha_{3}$ are significantly positive in the empirical results of $Y_{1}$, then the assumption $1 \mathrm{a}, 2 \mathrm{a}$ and $3 \mathrm{a}$ are supported, that is the quality of accounting information and the executive background can facilitate the credit availability of enterprises; If the coefficients $\alpha_{1}, \alpha_{2}$ and $\alpha_{3}$ are also significantly positive in the regression results of the explained variable $\mathrm{Y}_{4}$, then the assumption that $1 \mathrm{~b}, 2 \mathrm{~b}$ and $3 \mathrm{~b}$ are also verified, that is the quality of accounting information and the background of executives both facilitate the proportion of long-term credit of enterprises. The influence of relevant factors on the short-term and long-term credit availability will be tested by the empirical analysis of the explained variables $\mathrm{Y}_{2}$ and $\mathrm{Y}_{3}$. At the same time, it will also provide an explanation for the regression analysis of credit availability $\mathrm{Y}_{1}$ and long-term credit ratio $\mathrm{Y}_{4}$, so the conclusion of the paper will be more reliable.

Equation 6 introduces the cross multiplicative term $\mathrm{AQ}_{\mathrm{i}, \mathrm{t}} \times$ $\mathrm{TMB}_{\mathrm{i}, \mathrm{t}}$ between variables to judge the effect of accounting information quality on the credit effect of executive background, and the executive financial background $\mathrm{FB}_{\mathrm{i}, \mathrm{t}}$ and the executive political background $\mathrm{PB}_{\mathrm{i}, \mathrm{t}}$ respectively are substituted into the position of the executive background $\mathrm{TMB}_{\mathrm{i}, \mathrm{t}}$, then the model tests assumptions 4 and 5 . If $\beta_{3}$ is significantly negative, the empirical results support assumptions 4 and 5 .

\section{Empirical Results Analysis}

\subsection{Descriptive Statistics of Major Variables}

The main variables are analyzed based on data collected and reducted. The results are as follows: The bank loan availability of different SMEs $Y_{1}$ and the short-term and long-term credit availability $\left(\mathrm{Y}_{2}\right.$ and $\left.\mathrm{Y}_{3}\right)$ have great differences. The difference in the availability of short-term credit is greater than that of long-term credit, so it can be inferred that the influence of relevant factors on short-term credit is more significant; According to the average value of $\mathrm{Y}_{4}$, the ratio of long-term credit to SMEs is very small and the bank credit of SMEs is mainly short-term credit, so it is difficult to obtain long-term credit. According to the descriptive statistical results of the main explanatory variables, the SMEs having executives with financial background are fewer, while SMEs having different degree of political background are larger. Meanwhile, the political background of executives varies from sample to sample. The accounting information quality of at least half of the sample enterprises is lower than the AQ average of SMEs, reflecting that the accounting information quality of SMEs is generally low; The standard deviation of sample enterprises' AQ is very large, meaning that the accounting information quality of different SMEs is varies considerably. 
Table 1. Descriptive statistics of the main variables.

\begin{tabular}{lllll}
\hline & mean value & median & standard deviation & sample size \\
\hline Y1 & 0.4055 & 0.1264 & 0.6218 & 495 \\
Y2 & 0.2904 & 0.0909 & 0.4504 & 495 \\
Y3 & 0.1149 & 0 & 0.2971 & 495 \\
Y4 & 0.0891 & 0 & 0.1369 & 348 \\
FB & 0.5616 & 0 & 0.9153 & 495 \\
PB & 9.7212 & 8 & 7.5514 & 495 \\
AQ & 133.90 & 21 & 1008.6 & 495 \\
\hline
\end{tabular}

Note: due to the absence of bank credit in an enterprise in a certain year, the data of the long-term credit in that year are invalid and missing.

\subsection{Empirical Analysis}

\subsubsection{Analysis on the Effect of Single Factor Loan}

Equation 5 is used to test whether the influence of executive background and accounting information quality on the scale and structure of bank credit is consistent with the theoretical analysis. The regression results are shown in Table 2. For the test of credit scale effect, when the explanatory variable is bank credit availability $\mathrm{Y}_{1}$, the coefficients of AQ, FB and PB are significantly positive. It is consistent with the hypothesis of $1 \mathrm{a}, 2 \mathrm{a}$ and $3 \mathrm{a}$, indicating that the quality of the accounting information of SMEs and the financial and political background of executives can indeed facilitate the availability of the bank's credit. Compared the three coefficients, the loan effect of executive financial background is the most significant, obviously stronger than the effect of executive political background.
For the influence of the term structure of credit, this paper mainly analyzes the regression results of $\mathrm{Y}_{2}, \mathrm{Y}_{3}, \mathrm{Y}_{4}$ with various explanatory variables. The results are as follows: (1) The regression results of short-term credit availability $\mathrm{Y}_{2}$ show that the quality of accounting information and executive background can enhance the availability of short-term credit for SMEs; (2) The regression results of long-term credit availability $\mathrm{Y}_{3}$ show that the political background of executives does not significantly enhance long-term credit of SMEs, inconsistent with hypothesis $3 \mathrm{~b}$. While the quality of accounting information and the financial background of executives have a positive effect on long-term loans for enterprises, supporting hypothesis $1 \mathrm{~b}$ and $2 \mathrm{~b}$; (3) The empirical results of the ratio of long-term credit $\mathrm{Y}_{4}$ support the assumption $1 \mathrm{~b}$, that is the SMEs with high accounting information quality can obtain a higher proportion of long-term loans. However, it contradicts the assumptions $2 \mathrm{~b}$ and $3 \mathrm{~b}$ that the executive background can increase the proportion of long-term credit of enterprises. This contradiction can be explained according to the regression results of $\mathrm{Y}_{2}, \mathrm{Y}_{3}$. Specifically, higher accounting information quality can facilitate both short-term and long-term credit of enterprises and play a greater role in long-term loans. Therefore, the regression results of $\mathrm{Y}_{4}$ support the assumption 1b. However, the executive background characteristic can significantly promote short-term credit, but the role of long-term credit promotion is relatively weak, so the effect on long-term credit ratio $\mathrm{Y}_{4}$ is not obvious.

Table 2. Regression results of Model 1.

\begin{tabular}{lllll}
\hline & Y1 & Y2 & Y3 & Y4 \\
\hline AQ & $0.0001 * * *(8.90)$ & $0.0000 * *(2.47)$ & $0.0001 * * *(3.17)$ & $0.0000 *(1.83)$ \\
FB & $0.2608 * * *(6.12)$ & $0.1759 * * *(4.15)$ & $0.0827 * * *(3.04)$ & $0.0161(1.52)$ \\
PB & $0.0133 * * *(2.79)$ & $0.0093 * * *(2.64)$ & $0.0034(1.30)$ & $-0.0001(-0.10)$ \\
Income & $0.0146 *(1.92)$ & $0.0043(0.93)$ & $0.0102 *(1.93)$ & $0.0029 *(1.66)$ \\
LiqR & $-0.0099 *(-2.29)$ & $-0.0088 * *(-2.51)$ & $-0.0011(-0.49)$ & $0.0022(0.10)$ \\
FixR & $0.3919(1.01)$ & $0.3648(1.45)$ & $0.0602(0.28)$ & $-0.0430(-0.45)$ \\
Roa & $-0.3682(-0.69)$ & $-0.6228(-1.54)$ & $0.2735(1.29)$ & $0.2388(1.24)$ \\
year & yes & yes & yes & yes \\
C & $0.0133 * * *(2.79)$ & $0.0324(0.32)$ & $-0.0514(-1.04)$ & $0.0687 * *(2.11)$ \\
\hline
\end{tabular}

Note: $* * *, * * *$ respectively shows that the explanatory variables are significant at the level of $10 \%, 5 \%$ and $1 \%$. The data in the () represents the corresponding $\mathrm{t}$ value, rounded to the ten thousand points.

\subsubsection{Analysis of the Loan Effect Based on Factors Interaction}

Equation 6 tests the interaction of accounting information quality differences and loan effects of executive background characteristics. The empirical results are shown in Table 3. The left half of Table 3 is the test result of hypothesis 4 and the right half of Table 3 is the test result of hypothesis 5 .

For hypothesis 4 , the regression of the explained variable $Y_{1}$ shows that: (1) The coefficient of $A Q^{*} F B$ is not significant, meaning that the loan effect of executives financial background is not significantly affected by the quality of accounting information and is not consistent with hypothesis 4; (2) The test result of short-term credit availability $\mathrm{Y}_{2}$ also does not support hypothesis 4, because the intersection of AQ and FB is significantly positive, implying that the quality of accounting information and the role of executive financial background on short-term loans are complementary. That is, the low-quality accounting information leads to a significant decline on the short-term loan effect of the executive financial background. Or conversely, when the quality of accounting information is improved, the short-term loan effect of the executives financial background is more significant; (3) The empirical results of long-term credit availability $Y_{3}$ and $Y_{4}$ show that the coefficient of $A Q^{*} \mathrm{FB}$ is significantly negative, implicating that the lower the quality of accounting information is, the more obvious the long-term loan effect of executive financial background of SMEs is. Conversely, when the quality of accounting information is improved, the role of the executive financial background in facilitating long-term lending has weakened, which supports hypothesis 4 . So the interaction relation between the quality of accounting information and the executives financial background is 
obviously different because of the different loan periods and there are complementary effects on short-term loans and substitution effects on long-term loans. Therefore, AQ*FB does not play a significant role in enterprise bank credit.

For Hypothesis 5, the empirical result of the explanatory variable $Y_{1}$ shows that: (1) The low quality accounting information will obviously weaken the loan effect of the executive political background. Conversely, when the accounting information quality is improved, the PB loan effect of the executive political background will increase significantly, which is not consistent with hypothesis 5. (2)
The empirical conclusion for $\mathrm{Y}_{2}-\mathrm{Y}_{4}$ is basically consistent with the conclusion for explanatory variable financial background FB. It is briefly summarized as follows: In the short term, the lower the quality of accounting information is, the weaker the loan effect of the executive political background is; While in the long term, the lower the quality of accounting information is, the more obvious the loan effect of the executive political background is. In other words, the quality of accounting information and the executive political background have complementary relation with short-term loans and have substitute relation with long-term loans.

\section{Research Conclusions and Recommendation}

Table 3. Model 2 regression results of interaction between variables.

\begin{tabular}{|c|c|c|c|c|c|c|c|c|}
\hline & Y1 & Y2 & Y3 & Y4 & Y1 & Y2 & Y3 & Y4 \\
\hline AQ & $0.0001^{* * *}(2.85)$ & $-0.0000^{*}(-1.70)$ & $0.0002^{* * *}(6.10)$ & $0.0000^{* * *}(3.95)$ & $0.0001^{* * *}(5.86)$ & $0.0000(0.94)$ & $0.0001^{* * *}(8.35)$ & $0.0000^{* * *}(4.49)$ \\
\hline FB & $0.2974^{* * *}(6.21)$ & $1869^{* * *}(3.98)$ & $0.1100^{* * *}(3.80)$ & $0.0197^{* *}(1.98)$ & 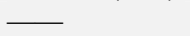 & - & {[} & \\
\hline PB & - & - & - & - & $0.0221^{* * *}(3.60)$ & $0.0141^{* * *}(3.10)$ & $0.0076^{* * *}(2.58)$ & $0.0009(0.68)$ \\
\hline $\mathrm{AQ} * \mathrm{FB}$ & $0.0000(0.23)$ & $0.0000^{* * *}(3.90)$ & $-0.0000^{* * *}(-4.65)$ & $\begin{array}{l}-0.0000^{* * *} \\
(-3.36)\end{array}$ & 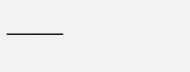 & - & - & - \\
\hline $\mathrm{AQ} * \mathrm{~PB}$ & - & - & - & - & $0.0000^{* *}(2.29)$ & $0.0000^{* * *}(6.00)$ & $\begin{array}{l}-0.0000^{* *} \\
(-2.22)\end{array}$ & $-0.0000^{*}(-1.73)$ \\
\hline Income & $0.0149^{*}(1.77)$ & $0.0045(0.91)$ & $0.0102^{*}(1.91)$ & $0.0292^{*}(3.15)$ & $0.0127(1.53)$ & $0.0030(0.59)$ & $0.0096^{*}(1.76)$ & $0.0028(1.56)$ \\
\hline LiqR & $-0.0110^{* *}(-2.47)$ & $-0.0098^{* * *}(-2.63)$ & $-0.0012(-0.54)$ & $0.0002(0.10)$ & $\begin{array}{l}-0.0120^{* *} \\
(-2.31)\end{array}$ & $\begin{array}{l}-0.0103^{* *} \\
(-2.55)\end{array}$ & $-0.0017(-0.69)$ & $0.0003(0.13)$ \\
\hline FixR & $0.4486(1.11)$ & $0.3814(1.44)$ & 0.1031 & $-0.0350(-0.37)$ & $0.2433(0.57)$ & $0.2546(0.93)$ & 0.0250 & $-0.0465(-0.48)$ \\
\hline Roa & $-0.2234(-0.40)$ & $-0.5269(-1.29)$ & $0.3176(1.42)$ & $0.2375(1.23)$ & $-0.8267(-1.38)$ & $-0.8926^{*}(-1.98)$ & $0.0813(0.39)$ & $0.2026(1.07)$ \\
\hline year & yes & yes & yes & yes & yes & yes & yes & yes \\
\hline $\mathrm{C}$ & $0.0859(0.70)$ & $0.1234(1.22)$ & $-0.0447(-1.01)$ & $0.0622^{* *}(2.10)$ & $0.0960(0.79)$ & $0.1240(1.23)$ & $-0.0304(-0.66)$ & $0.0705^{* *}(2.08)$ \\
\hline
\end{tabular}

Note: $* * *, * * *$ respectively shows that the explanatory variables are significant at the level of $10 \%, 5 \%$ and $1 \%$. The data in the () represents the corresponding $\mathrm{t}$ value, rounded to the ten thousand points.

Based on the empirical results, this paper puts forward the following conclusions: (1) In general, the quality of accounting information, executive financial background and political background of SMEs can significantly facilitate the availability of credit. Among these three factors, executive financial background plays the most important role in facilitating the SME's ability of getting credit. (2) Regarding to the term structure of credit, the quality of accounting information and the characteristics of executive background can enhance the short-term credit availability of SMEs and the executive financial background is still the most important; However, the impact of executive background on long-term loans is relatively weak and the quality of accounting information plays a relatively important role in improving long-term loans for SMEs, indicating that the quality of accounting information is more important than the executive background when banks make long-term loan decisions. (3) The lower the quality of accounting information is, the weaker the role of the political background of SMEs executives in facilitating the availability of credit is, but the effect of high-level financial background on the availability of credit can not change significantly. It further shows that the financial background of executives helps to make up for the lack of accounting information, while the role of political background is more dependent on the quality of accounting information. (4) The interactive relationship between accounting information quality and executive background on SMEs credit is obviously different due to the difference of loan term. These two factors have complementary effects on short-term credit and substitution effects on long-term credit. Therefore, after improving the quality of SMEs accounting information, the impact of the executive background on short-term loans is enhanced, while the impact of the executive background on long-term loan is weakened.

The pollical implication of the above research conclusions is: With respect to SMEs, they should pay attention to the construction of financial system, improve the quality of accounting information, increase the proportion of long-term credit and optimize the credit structure of enterprises. In order to break through the short-term financing dilemma, SMEs should pay attention to the accumulation of human capital and social capital, appropriately recruit people with political or financial background, especially those in the financial industry as corporate executives and utilize the combination of soft and hard information to improve the availability of loans. With respect to banks, facing the situation that the accounting information quality of SMEs is low, banks should fully excavate the "soft information" such as the executive background characteristics, actively innovate credit technology and solve the urgent capital needs of SMEs. At the same time, banks should improve the ability of identifying the quality of accounting information of SMEs, carefully evaluate 
the credit information of SMEs and properly strengthen the long-term credit support for SMEs on the premise of considering the principle of "three properties". Government departments should strengthen the supervision intensity of the quality of accounting information disclosure in SMEs, improve the legal system construction and strengthen the enforcement to better protect the interests of beneficiaries.

\section{Acknowledgements}

This paper is one of the periodic achievements of the general project of the National Social Science Fund, and the project is "Research on the realization of the function of small and Medium-sized Financial institutions serving small and Medium-sized Enterprises in China" (13BGL040).

\section{References}

[1] Xiao Zuoping, Liao Li. Does Corporate Governance affect debt maturity levels?-empirical data from listed companies in China [J]. Managing the world,2008, (11): 143-156.

[2] Lu Zhengfei, Han Xia, Chang Qi. A study on the relationship between long-term debt and Investment behavior: an empirical Analysis based on Chinese listed companies [J]. Managing the world 2006, (01): 120-128.

[3] Rao Yanchao, Hu Yiming. Investigation and Analysis on the use of Accounting Information in Bank Credit [J]. Accounting Research,2005. (4): 36-41.

[4] Ma Rujing, Jiang Chao, Tang Xuesong. Earnings quality of debt Enterprises and Bank loan Decision-Making [J]. Financial Science: 2015, (10): 55-63.

[5] Lin Zhonggao, Yang Yuxin. Risk prompt Information and Bank Credit Decision--A study on the text Information of A-share listed companies' Annual report [J]. Journal of Anhui normal University (Humanities and Social Sciences) ,2017,45 (2): 245-255.

[6] Hackbarth, D. Managerial Traits and Capital Structure Decisions[J]. Journal of Financial and Quantitative Analysis, 2008,(43):843-882.

[7] Zhang Zhaoguo, Liu Yongli, Tan Duojiao. Managerial background characteristics and accounting conservatism-empirical data from Chinese listed companies [J]. Accounting Research: 2011, (7): 11-18.

[8] Cao Yugui, Xiao Chaolan. A study on the relationship between the background characteristics of Executive team and enterprise debt financing [J]. Accounting Bulletin, 2014, (6): 75-77.

[9] Tang Jianxin, Lu Jianlong, Yu Minggui. Bank Relations, political Relations and Private Enterprise loans- empirical evidence based on China's Private listed companies [J]. Economic Review, 2011, (3): 51-58.

[10] Yu Minggui, Pan Hongbo. Ownership, Commercial Credit and Credit Resource allocation efficiency [J]. Economic Management, 2010, (8): 106-117.
[11] Guo Tianyong, Li Xianwen. Empirical Analysis of Relational Lending and SMEs financing [J]. Financial Forum, 2006, (4): 49-53.

[12] Yuan Ruiying. Research on the influence of Accounting Information Transparency on Credit risk [J]. Accounting Newsletter, 2014, (24): 3-6.

[13] Bhattacharya N., Desai H., Venkataraman K.. Does Earnings Quality Affect Information Asymmetry:Evidence from Trading Costs[J]. Contemporary Accounting Research, 2013,30(2): 482-516.

[14] Zhang Zhong, Wu Xiaojun. Quality of Accounting Information and Mathematical Analysis of small and Medium-sized Enterprises financing [J]. Journal of Hubei University for nationalities (Natural Science Edition),2007, 25 (2): 230-233.

[15] Bharath S.T.,Sunder J.,Sunder S. V.. Accounting Quality and Debt Contracting[J]. Accounting Review,2008,83(1):1-28.

[16] Graham J.R.,S. Li,J. Qiu. Corporate Misreporting and Bank Loaning Contracting[J]. Journal of Financial Economics,2008,89(1):44-61.

[17] Lu Zhengfei, Zhu Jigao, Sun Lengxia. Earnings Management, Accounting Information and Bank debt contract [J]. Manage the world, 2008, (3): 152-158.

[18] Jiang Dongsheng. Who got a long term loan? [J] Managing the world, 2012, (7): 167-169.

[19] Adam R.,Ferreira D.. A Theory of Friendly Boards[J]. The Journal of Finance,2007, 62(1):217-250.

[20] Faccio,M.,Masulis,Ronald,W.,and Mc Connell,John,J.. Political Connections and Corporate Bailouts[J]. The Journal of Finance,2006(6):2597-2635.

[21] Luo Danglun, Zhen Liming. Private Control, political Relations and Enterprise financing constraints-the Management data based on Chinese Private listed companies [J]. Financial Studies, 2008, (12): 164-178.

[22] Hong Yitian, Chen Jinlong. Social capital, ownership attributes and financing constraints [J]. Accounting Newsletter, 2014, (5): 26-29.

[23] Ciamarra E.S.. Monitoring By Affiliated Bankers on Board of Directors: Evidence from Corporate Financing Outcomes[J]. Financial Management,2012,41(3):665-712.

[24] Yu Minggui, Pan Hongbo. Political connection, Institutional Environment and Private Enterprise Bank loan [J]. Managing the world, 2008, (8): 9-21.

[25] Yuan Chunsheng. A study on the impact of political connections on Credit financing of Private Enterprises [J]. Journal of Shanxi University (philosophy and Social Sciences),2014, 37 (6): 125-130.

[26] Rao Pingui, Jiang Guohua. A study on the impact of Monetary Policy on the interaction between Bank Credit and Commercial Credit [J]. Economic studies, 2013, (1): 68-82.

[27] Wu Peng, Zhong Weijun, Wu Yingyu. Research on early warning of Financial crisis based on modified Jones earnings Management Model [J]. Business economy and Management, 2010, (8): 67-74. 